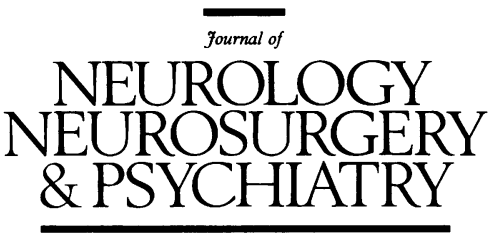

Editorial

\title{
Antiglycolipid antibodies in peripheral neuropathy: fact or fiction?
}

The past decade has seen the emergence of a large field of research investigating the concurrence of antiglycolipid antibodies and peripheral neuropathy (see reviews ${ }^{1-4}$ ). Initial scepticism about the significance of antiganglioside antibodies is being replaced by a widespread realisation that these antibodies directly contribute to the pathogenesis of neuropathy. Two incompletely resolved issues which cast doubt on this relation are that raised concentrations of antiglycolipid antibodies are very widespread in normal and disease controls and antiglycolipid antibodies may be either present or absent in clinically indistinguishable neuropathy syndromes. By contrast, some syndromes such as Miller Fisher syndrome, are very tightly linked to a specific antiglycolipid antibody in which conclusive passive transfer studies have been performed. Refining the clinicoserological associations to aid in diagnosis and to monitor disease progress through antiglycolipid antibody measurements is becoming more relevant to patient management. From the research point of view, considerable efforts are being made to identify new antibody specificities and to elucidate the precise mechanisms of action of antiglycolipid antibodies. The purpose of this editorial is to put a large body of confusing and often conflicting data into a balanced clinical perspective with particular emphasis on currently recognised clinical syndromes and guidance about requesting and interpreting antiglycolipid antibody assays.

\section{Glycolipid terminology, structure, and function}

An early hurdle to cross concerns the complexities of glycolipid and ganglioside terminology. Glycosphingolipids are composed of the long chain aliphatic amine sphingosine (acylated ceramide) attached to one or more sugars (hexoses). The ceramide is immersed in the membrane lipid bilayer with the carbohydrate structure exposed extracellularly. A single hexose linked to ceramide (monohexosyl-ceramide) is termed a cerebroside, the most abundant of which in humans is galactocerebroside (galactosyl-ceramide). Sulphatide is galactocerebroside sulphated in the carbon-3 position and is a major component of peripheral nerve myelin and an autoantigen in predominantly sensory neuropathies. ${ }^{5.9}$

Gangliosides are complex glycosphingolipids that, by definition, must contain at least one sialic acid residue. Sialic acid is a generic term for $\mathrm{N}$-acylneuraminic acid, the acyl group generally being acetyl in the human nervous system (as opposed to glycolyl), hence $\mathrm{N}$-acetylneuraminic acid, commonly abbreviated to NeuNAc or
NANA. The sialic acid(s) are attached to the internal or the terminal galactose of an oligosaccharide core composed of up to four sugars with the following sequence: ceramide-glucose-galactose- $\mathrm{N}$-acetylgalactosamine-galactose. Traditionally, gangliosides are named according to Svennerholm ${ }^{1011}$ with the following formula: G refers to ganglio; $M, D, T$, and $Q$ refer to the number of sialic acid residues (mono, di, tri, and quad respectively); arabic numerals and lower case letters refer to the sequence of migration as determined by thin layer chromatography. Although dependent on the solvent system used, bulky gangliosides with a longer oligosaccharide core and more sialic acid will migrate more slowly than the smaller gangliosides. For example, for three of the monosialogangliosides, GM1 (having a four sugar oligosaccharide core, Cer-Glc-Gal-GalNAc-Gal) migrates more slowly than GM2 (a three sugar oligosaccharide, Cer-Glc-Gal-GalNAc), which migrates more slowly than GM3 (a two sugar oligosaccharide, Cer-Glc-Gal). Likewise, GD1b runs ahead of GT1b, which runs ahead of GQ1b, as they contain two, three, and four sialic acids respectively. The figure shows the structure of GD1b. There are four major gangliosides in the brain (GM1, GD1a, GD1b, GT1b) and many minor gangliosides in brain and peripheral nerve tissues, which are developmentally regulated and spatially segregated in a wide range of patterns across different species. Many different gangliosides can be autoantigens in peripheral neuropathy, some of which have not been identified. ${ }^{1}$

Paragloboside is a neutral glycolipid (Cer-Glu-GalGlcNAc-Gal), which, when sialylated on the terminal galactose (sialosylparagloboside, SGP), is a major peripheral nerve glycolipid, also known as LM1. ${ }^{12}$ Substitution of the terminal sialic acid for sulphated glucuronic acid forms sulphated glucuronyl paragloboside (SGPG).1314 Both LM1 and SGPG are also important peripheral nerve autoantigens in neuropathy. ${ }^{813}$

All antiglycolipid antibodies associated with neuropathy react with epitopes on the carbohydrate region of the glycolipid molecules. Because these carbohydrate structures are often present on several different glycolipids, glycoproteins, and other carbohydrate rich molecules such as bacterial lipopolysaccharides, there is considerable potential for shared reactivity. For example, (a) autoantibodies that react with the sulphated glucuronic acid epitope on SGPG also react with similar epitopes on many other neural glycoproteins including the myelin associated glycoprotein (MAG) $)^{13-15}$ and the peripheral 


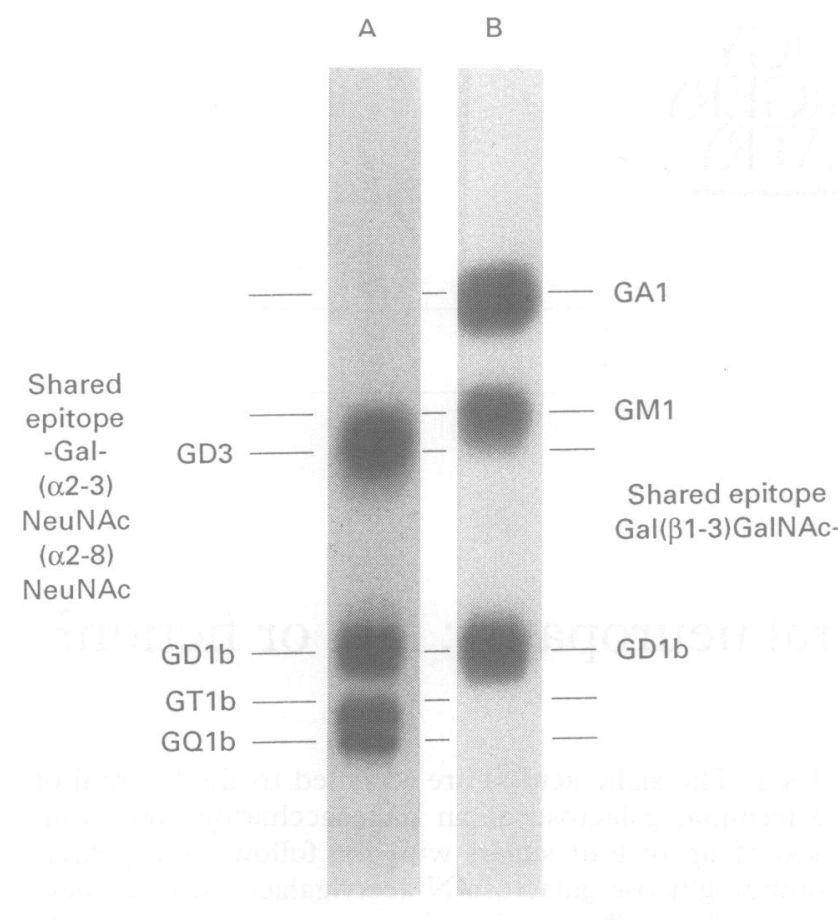

Structure of GD1b ganglioside

$\begin{aligned} & \text { Gal }(\beta 1-3) \text { GalNAc }(\beta 1-4) \text { Gal }(\beta 1-4) \text { Glc }(\beta 1-1) \text { ceramide } \\ &(\alpha 2-3) \\ & \text { NeuNAc } \\ &(\alpha 2-8) \\ & \text { NeuNAc }\end{aligned}$

Thin layer chromatogram of $1 \mu \mathrm{g}$ each of asialo-GM1, GM1, GD3, $G D 1 b, G T 1 b$, and $G Q 1 b$, immunostained with two monoclonal IgM antiganglioside antibodies derived from patients with neuropathy and showing characteristic patterns of reactivity (see Willison et al ${ }^{\text {s2 }}$ for method). Lane $A$ shows an antibody derived from a patient with a chronic ataxic neuropathy and IgM paraproteinaemia reactive with disialosyl epitopes common to GD3, GD1b, GT1b, and GQ1b. ${ }^{22}$ Lane $B$ shows an antibody derived from an anti-GM1 positive patient reactive with the Gal(B1-3) GalNAc epitope common to GM1, GD1b, and asialo-GM1.

nerve compact myelin protein $P_{0}{ }^{16}, \quad(b)$ the $\mathrm{Gal}(\beta 1-3)$ GalNAc epitope found on GM1 ganglioside is also present on asialo-GM1 and GD1b (see figure) ${ }^{17-20}$ and the complete GM1 carbohydrate sequence is present on Campylobacter jejuni lipopolysaccharide (LPS), ${ }^{21}$ Campylobacter enteritis being a common prodromal infection in patients with Guillain-Barré syndrome, ${ }^{22-25}$ a proportion of whom have anti-GM1 antibodies. ${ }^{26}{ }^{27}$

Glycolipids, including gangliosides, regulate many diverse physiological processes, ${ }^{28}{ }^{29}$ including extensive modulation of neural cell function. ${ }^{30}$ They are asymmetrically located in the plasma membrane, anchored in the bilayer by their ceramide tail, exposing their sialylated oligosaccharide core extracellularly, a site readily accessible to antibody binding. They are highly enriched in neural membranes, particularly synaptic regions. They interact with growth factor receptors, ion channels, and cell recognition/adhesion molecules and have widespread effects on signal transduction systems. At the cellular level, they influence such diverse events as cell survival, differentiation, synaptogenesis and synaptic transmission, and neurite outgrowth. In vivo effects include accelerated restoration of function in injured tissues and neuroprotection-for example, against glutamate induced neuronal injury. Considerable research is currently focused on increasing our understanding of ganglioside function.

\section{Antiganglioside antibody assays: methodology and interpretation}

Assaying serum samples for antiganglioside and antiglycolipid antibodies is a process with many pitfalls. There is no standardised assay method and the literature on this subject is crowded with different protocols ${ }^{31}$ that claim superiority. Two multicentre studies with coded samples have shown good agreement on clearly positive or negative cases but discrepancies appear with borderline samples, which may nevertheless be of important clinical relevance. ${ }^{32}{ }^{33}$ Most centres use a combination of enzyme linked immunosorbent assay (ELISA) with thin layer chromatography overlay as a confirmatory test. Critical factors that influence assay results include $(a)$ the choice of ELISA plates, taking into account manufacture related batch to batch variations and subsequent storage conditions; $(b)$ the temperature at which the assay is performed; (c) the duration of serum incubation; (d) washing and blocking buffer composition, particularly the presence or absence of detergent and the choice of blocking protein; (e) sample layout on ELISA plates, with particular attention to plate stacking artefacts and edge effects. These factors need to be built into stringent quality control practice in all laboratories performing assays, particularly when results influence decisions about diagnosis and clinical management.

Assay results are usually reported as titres calculated by end point analysis (the lowest serum dilution that still gives a raised optical density reading by ELISA). When interpreting an assay result, consideration must be given to the methodology used and the normal range established for that laboratory. Because antiganglioside antibodies form part of the normal antibody/autoantibody repertoire, ${ }^{34}{ }^{35}$ they are commonplace in normal and disease control serum samples. ${ }^{36-40}$ For example, moderately high IgM and IgG titres $\left(>1 / 10^{3}<1 / 10^{4}\right)$ against asialoGM1 and sulphatide are typically found in normal serum samples and are thus not likely to be relevant at this level; by contrast, an anti-GM1 IgM titre of $1 / 10^{3}$ is likely to be relevant as this is above the upper limit of the normal range (around 1/500) for this antigen in most laboratories.

\section{Antiglycolipid antibody markers for clinical syndromes}

The table lists the main clinical syndromes with a well defined antiglycolipid antibody specificity. In some situations, the antiglycolipid antibody assay result will corrob-

Clinical syndromes associated with specific antiglycolipid autoantibodies

\begin{tabular}{|c|c|c|}
\hline Clinical syndrome & $\begin{array}{l}\text { Autoantibody specificity and } \\
\text { isotype }\end{array}$ & References \\
\hline $\begin{array}{l}\text { Chronic sensorimotor } \\
\text { demyelinating } \\
\text { neuropathy }\end{array}$ & $\begin{array}{l}\text { Monoclonal IgM antibodies } \\
\text { to SGPG, SGLPG, } \\
\text { MAG, and Po }\end{array}$ & $\begin{array}{l}1-3,13-16 \\
41-46\end{array}$ \\
\hline $\begin{array}{l}\text { Chronic axonal sensory } \\
\text { neuropathy }\end{array}$ & $\begin{array}{l}\text { IgM antibodies to } \\
\text { sulphatide }\end{array}$ & $5-9$ \\
\hline $\begin{array}{l}\text { Chronic large fibre } \\
\text { sensory neuropathy } \\
\text { with ataxia }\end{array}$ & $\begin{array}{l}\text { Monoclonal IgM antibodies } \\
\text { to gangliosides containing } \\
\text { NeuNAc }(\alpha 2-8) \text { NeuNAc } \\
\text { epitopes }\end{array}$ & $47-53$ \\
\hline $\begin{array}{l}\text { Multifocal motor } \\
\text { neuropathy }\end{array}$ & $\begin{array}{l}\text { IgM antibodies to GM1 } \\
\text { and related Gal }(\beta 1-3) \\
\text { GalNAc bearing glycolipids }\end{array}$ & $20,37-40,58$ \\
\hline Miller Fisher syndrome & $\begin{array}{l}\text { IgG antibodies to GQ1b } \\
\text { and GT1a }\end{array}$ & $54-56,70,71$ \\
\hline Guillain-Barré syndrome & $\begin{array}{l}\text { IgG, IgM and IgA antibodies } \\
\text { to GM1, GD 1 a, LM1, } \\
\text { sulphatide, and other } \\
\text { glycolipids }\end{array}$ & $\begin{array}{l}4,5,9,24,26 \\
37-39,40 \\
90-100\end{array}$ \\
\hline
\end{tabular}


orate a previously suspected diagnosis, such as multifocal motor neuropathy, or indeed alert the neurophysiologist to search carefully for conduction block in an apparent case of lower motor neuron disease in whom multifocal motor neuropathy was not suspected clinically. Alternatively, a positive result will further refine an existing diagnosis, such as paraproteinaemic neuropathy with anti-MAG specificity or will help to distinguish an important differential diagnosis, such as Miller Fisher syndrome, botulism, and brain stem demyelinating disease.

The first clinical syndrome in which antiglycolipid antibodies were identified was the IgM paraproteinaemic neuropathy associated with anti-MAG antibodies. ${ }^{41}{ }^{42}$ As well as reacting with MAG and other glycoproteins present in peripheral nerve, it was established that the antiMAG paraproteins also reacted with the previously unknown acidic glycolipid, SGPG, and its related homologue, sulphated glucuronyl lactosaminyl paragloboside (SGLPG). ${ }^{13-15}$ The clinical syndrome is of a relatively benign, late onset, chronic sensorimotor demyelinating neuropathy, often associated with tremor. ${ }^{4344} \mathrm{~A}$ pathological feature of note in nerve biopsies is the presence of widely spaced myelin. ${ }^{44-46}$ The anti-MAG specificity accounts for $50 \%$ of patients with $\operatorname{IgM}$ paraproteinaemic neuropathy; most of the remainder react with other glycolipids or gangliosides. ${ }^{1}$ Some anti-MAG paraproteins cross react with sulphatide ${ }^{67}$ and in addition, sulphatide can be a specific and sole antigen in patients with IgM paraproteinaemic, predominantly sensory, neuropathy. ${ }^{5-7}$ It is important to recognise, when evaluating cases of late onset demyelinating neuropathy, that low level paraproteins may be easily missed by standard electropheretic techniques and that sensitive screening methods should be employed.

Another increasingly well defined paraproteinaemic neuropathy syndrome is a chronic large fibre sensory neuropathy with prominent ataxia, first described in a single case report almost a decade ago $^{47}$ and subsequently reported by several groups. ${ }^{48-53}$ In these cases the IgM paraprotein reacts with gangliosides bearing NeuNAc(a2-8)NeuNAc linked disialosyl groups, including GD3, GD1b, GT1b, and GQ1b (figure). There is some variation in the fine specificity of the antibody between cases although the clinical pattern is fairly uniform. Some of these patients also have cold agglutinin disease by virtue of the presence of sialylated glycoprotein epitopes on human red blood cells. In addition, some cases have been reported with intermittent opthalmoplegia, ${ }^{47} 53$ thus producing a clinical syndrome reminiscent of Miller Fisher syndrome in which antibodies to disialylated gangliosides are also found..$^{54-56}$

Interest in multifocal motor neuropathy with demyelinating conduction block ${ }^{57}$ has been intense since it was recognised that patients with this syndrome may have antibodies to GM1 gangloiside. ${ }^{58}$ Early reports indicating a significant association between anti-GM1 antibodies and motor neuron disease/amyotrophic lateral sclerosis ${ }^{5960}$ were not confirmed by others ${ }^{37} 38$ 40 61-63 although there do seem to be very rare, unusual cases in which this occurs. ${ }^{17-19}$ We screen all patients with predominantly lower motor neuron syndromes for anti-GM1 antibodies. Many patients with multifocal motor neuropathy and anti-GM1 antibodies have a fairly stereotyped clinical picture comprising a chronic asymmetric motor syndrome, usually with distal onset in an upper limb, as previously described..$^{206-66}$ We have not found further subdivisions on the basis of antiganglioside serology useful, although they have been reported. ${ }^{67}$ These patients respond well, albeit temporarily, to intravenous immunoglobulin ${ }^{68}$ which is our routine treatment and can be regularly repeated. Our own experience with cyclophosphamide has been disappointing (lack of sufficient efficacy to warrant the high risks of toxicity) although others report success. ${ }^{69}$

Antiganglioside antibodies are also found in acute peripheral neuropathies where they appear transiently and are predominantly of the IgG class. The most clearly defined association is between anti-GQ1b ganglioside antibodies and Miller Fisher syndrome. ${ }^{54-56}$ The antiGQ1b antibodies cross react with GT1a in the series of cases reported by Chiba $\mathrm{et}_{\mathrm{al}}{ }^{70}$ and in all our cases to date (14/14) and with GD1b, GD3, or both in about half of our cases. Anti-GQ1b reactivity seems to specifically mark the presence of ophthalmoplegia: we have recently identified a case of acute ataxic, areflexic neuropathy without opthalmoplegia whose serum samples reacted only with GD1b and GD3, thereby lending support to this view. A recent report indicates that anti-GQ1b antibodies are also present in Bickerstaff's brain stem encephalitis, suggesting that there may be a common aetiological thread to both these conditions. ${ }^{71}$

In Guillain-Barré syndrome, a wide variety of antiganglioside antibodies have been reported in up to $50 \%$ of cases in different series (table); although no unifying patterns have yet emerged, they may do so in the future. Considerable debate surrounds the significance of antiGM1 antibodies in Guillain-Barré syndrome. In some studies, anti-GM1 antibodies mark a particularly severe form of the illness with prominent motor axonal involvement and poor recovery, ${ }^{26} 2772$ although this association is refuted by others. ${ }^{73} 74$ This issue may be resolvable by further subclassification of anti-GM1 antibodies by fine specificity. In this regard, our recent studies on a panel of cloned human anti-GM1 antibodies ${ }^{75}$ have shown considerable heterogeneity in their ability to bind antigen under different conditions and in their patterns of tissue reactivity. This may account for the apparent diversity of clinical expression of anti-GM1 antibody associated neuropathies and neuronopathies.

\section{The pathogenic relevance of antiglycolipid antibodies}

Despite considerable anomalies and complexities, good evidence is beginning to emerge from a variety of experimental models to support a direct role for antiganglioside antibodies in causing neuropathy. Clearly, other factors including cellular immune mechanisms may play a central part in pathogenesis. The subject is complicated by many factors common to developing an animal model for disease including qualitative and quantitative variations in glycolipid antigen composition in nerves from different species and the lack of well defined human antibodies for pathogenesis studies. The generation of disease associated human monoclonal antibodies should help to resolve this issue. ${ }^{75}$

Antibodies to SGPG, as found in the "anti-MAG" IgM paraproteinaemic neuropathy have been shown to cause demyelination and other pathological changes including widening of myelin lamellae, when injected locally into rodent nerve ${ }^{7677}$ and after systemic passive transfer to the chicken. ${ }^{78}$ An intriguing case of anti-MAG IgM paraproteinaemic neuropathy occurring in conjunction with hereditary motor and sensory neuropathy has been described, ${ }^{79}$ raising the possibility that pre-existing peripheral nerve abnormalities may predispose to the development of antinerve antibodies, a fact long recognised in experimental models of nerve injury. ${ }^{80}$

Experimental studies on anti-GM1 antibodies have 
shown a variety of neuropathic effects including demyelination and conduction block ${ }^{81-84}$ although these studies are clearly incomplete. ${ }^{8586}$ Antibodies to GM1/GD1b ${ }^{87}$ and gangliosides bearing disialosyl groups as found in chronic sensory neuropathies, ${ }^{88}$ are toxic to cultured motor neurons and dorsal root ganglion neurons respectively. It has also recently been shown that Miller Fisher syndrome serum containing anti-GQ1b antibody blocks neurotransmitter release in the mouse hemidiaphragm preparation, which we postulate accounts for the motor manifestations of the syndrome. ${ }^{89}$ Many groups are actively researching this field, which will undoubtedly reveal the pathogenic relation between antiglycolipid antibodies and neuropathy in more detail.

\section{Conclusion}

Antiglycolipid antibodies are here to stay as part of the clinical and experimental investigation of patients with peripheral neuropathy. The extent to which antiglycolipid antibody assays are requested, however, will depend on the investigative enthusiasm of individual neurologists as there are few circumstances in which positive or negative results play a critical part in patient diagnosis and management. The field is still in its infancy and a considerable amount of further research is necessary to identify putative antigens in seronegative cases, or to establish that such cases are not antibody mediated. This information will eventually filter into clinical practice and will hopefully direct clinicians towards appropriate treatment and monitoring of antibody mediated neuropathies.

The financial support of the Scottish Motor Neurone Disease Association and the Guillain-Barré Support Group of Great Britain and helpful discussions with Drs Norman Gregson and Donald Marcus are gratefully acknowledged.

HUGH J WILLISON epartment of Neurology, Institute of Neurological Sciences, Southern General Hospital,
Glasgow, G51 $4 T F$, UK

1 Quarles RH, Ilyas AA, Willison HJ. Antibodies to glycolipids in demyelinating diseases of the human peripheral nervous system. Chemistry and Physics of Lipids 1986;42:235-48.

2 Latov N. Antibodies to glycoconjugates in neurological disease. Clinical Aspects of Autoimmunity 1990;4:18-29.

3 Thomas PK, Willison HJ. Paraproteinaemic neuropathies. In: McLeod J, ed. Inflammatory neuropathies, Balliere's clinical neurology series. London: Balliere Tindall, 1994

4 Willison HI, Kennedy PGE. Gangliosides and bacterial toxins in GuillainBarre syndrome. F Neuroimmunol 1993;46:105-12.

5 van den Berg LH, Lankamp CLAM, de Jager AEJ, et al. Anti-sulphatide antibodies in peripheral neuropathy. $f$ Neurol Neurosurg Psychiatry 1994:56:1164-8.

6 Pestronk A, Li F, Griffin J, Feldman EL, et al. Polyneuropathy syndromes associated with serum antibodies to sulfatide and myelin-associated glycoprotein. Neurology 1991;41:357-62.

7 Ilyas AA, Cook SD, Dalakas MC, Mithen FA. Anti-MAG IgM paraproteins from some patients with polyneuropathy associated with IgM paraproteinaemia also react with sulphatide. $\mathcal{F}$ Neuroimmunol 1992;37. 85-92.

8 Fredman P, Vedeler CA, Nyland H, Aarli JA, Svennerholm L. Antibodies in sera from patients with inflammatory demyelinating polyradiculoneuropathy react with ganglioside LM1 and sulphatide of peripheral nerve myelin. I Neurol 1991;238:75-9.

9 Ilyas AA, Mithen FA, Dalakas MC, et al. Antibodies to sulphated glycolipids in Guillain-Barre syndrome. 7 Neurol Sci 1991;105:108-17.

10 Svennerholm L. Chromatographic separation of gangliosides. F Neurochem 1963;10:613-23.

11 IUPAC-IUB Commission on Biochemical Nomenclature (CBN). The nomenclature of lipids. Eur $\mathfrak{f}$ Biochem 1977;79:11-21.

$12 \mathrm{Li}$ Y-T, Mansson J-E, Vanier M-T, Svennerholm L. Structure of the major glucose-amine containing ganglioside of human tissues. $\mathcal{f} \mathrm{BiO}$ Chem 1973;248:2634-6.

13 Ilyas AA, Ouarles RH, MacIntosh TD, Dobersen MJ, Dalakas MC Brady RO. IgM in a human neuropathy related to paraproteinaemia binds to a . IgM in a tein and to a ganglioside. Proc Natl Acad Sci USA 1984;81:1225-9.

14 Chou DKH, Ilyas AA, Evans JE, Costello C, Quarles RH, Jungalwala FB. Structure of sulfated glucuronyl glycolipids in the nervous system reacting with $\mathrm{HNK}-1$ antibody and some IgM paraproteins in neuropathy. F Biol Chem 1986;261:11717-25.
15 Ariga $\mathrm{T}$, Kohriyama $\mathrm{T}$, Freddo $\mathrm{L}$, et al. Characterization of sulfated glucuronic acid containing glycolipids reacting with IgM paraproteins in patients with neuropathy 7 Biol Chem 1987;262:848-53.

16 Bollensen E, Steck AJ, Schachner M. Reactivity with the myelin glycoprotein $\mathbf{P}_{\mathrm{o}}$ in serum from patients with monoclonal IgM gammopathy and polyneuropathy. Neurology 1988;38:1266-70.

17 Freddo L, Yu RK, Latov N, et al. Gangliosides GM1 and GD1b are antigens for $\mathrm{M}$-proteins in a patient with motor neuron disease. Neurology

18 Latov N, Hays AP, Donofrio PD, et al. Monoclonal IgM with unique reactivity to gangliosides GM1 and GDIb and to lacto-N-tetraose in two patients with motor neuron disease. Neurology 1988;38:763-8.

19 Nardelli E, Steck AJ, Barkas T, et al. Motor neuron disease and monoclonal IgM with antibody activity against GM1 and GD1b gangliosides. Ann Neurol 1988;23:524-8.

20 Pestronk A. Invited review: motor neuropathies, motor neuron disorder and anti-glycolipid antibodies. Muscle Nerve 1991;14:927-36.

21 Yuki N, Taki T, Inagaki F, et al. A bacterium lipopolysaccharide that elicits Guillain-Barre syndrome has a GM1 ganglioside-like structure. f Exp Med 1993;178:1771-5.

22 Kaldor J, Speed BR. GBS and Campylobacter jejuni: a serological study. $B M 7$ 1984;288: 1867-70.

23 Winer JB, Hughes RAC, Anderson MJ, Jones DM, Kangro $\mathrm{H}$, Watkin RFP. A prospective study of acute idiopathic neuropathy. II Antecedent events. $\mathcal{F}$ Neurol Neurosurg Psychiatry 1988;51:613-8.

24 Koblar SA, Gregson NA, Hughes RAC, Doherty P, Walsh FS. Camplyobacter neuropathy. Neurology 1991;41:1327-8.

25 Griffin JW, Ho TW-H. The Guillain-Barre syndrome at 75: The Campylobacter connection. Ann Neurol 1993;34:125-7.

26 Yuki N, Yoshino H, Sato S, Miyatake T. Acute axonal polyneuropath associated with anti-GMl antibodies following Campylobacter enteritis. Neurology 1990;40:1900-2.

27 Gregson NA, Koblar S, Hughes RAC. Antibodies to gangliosides in Guillain-Barre syndrome: specificity and relationship to clinical features. $Q \mathcal{O}$ Med 1993;86:111-7.

28 Merrill AH, Hannun YA, Bell RM. Introduction: sphingolipids and their metabolites in cell regulation. Adv Lipid Res 1993;25:1-21.

29 Hakamori S. Bifunctional role of glycosphingolipids. I Biol Chem 1990;265:18713-6.

30 Tettemanti G, Riboni L. Gangliosides and modulation of function of neural cells. Adv Lipid Res 1993;25:235-67.

31 Kornberg AJ, Pestronk A. The clinical and diagnostic role of anti-GM1 antibody testing. Muscle Nerve 1994;17:100-4.

32 Marcus DM, Latov N, Hsi BP, et al. Measurement and significance of antibodies against GM1 ganglioside. F Neuroimmunol 1989;25:255-9.

33 Zielasek J, Ritter G, Magi S, Hartung HP, Toyka KV, and participating laboratories. A comparative trial of anti-glycoconjugate antibody assays: IgM antibodies to GM1. F Neurol 1994;241:475-80.

34 Lee K-W, Inghrami G, Spatz LA, Knowles DM, Latov N. The B-cells that express anti-MAG antibodies in neuropathy and non-malignan monoclonal gammopathy belong to the CD5 subpopulation f Neuroimmunol 1991;31:83-8.

35 Heidenreich F, Leifeld L, Jovin T. T-cell dependent activity of ganglioside GMI-specific B cells in Guillain-Barre syndrome and multifocal motor neuropathy in vitro. 7 Neuroimmunol 1994;49:97-108.

36 Endo T, Scott DD, Stewart SS, Kundu SK, Marcus DM. Antibodies to glycosphingolipids in patients with multiple sclerosis and SLE. I Immunol 1984;132:1793-7.

37 Sadiq SA, Thomas FP, Kilidirias K, et al. The spectrum of neurological disease associated with anti-GM1 antibodies. Neurology $1990 ; 40$ 1067-72.

38 Adams D, Kuntzer T, Burger D, et al. Predictive value of anti-GM1 antibodies in neuromuscular diseases: a study of 180 sera. $\mathcal{f}$ Neuroimmuno 1991;32:223-30

39 Lamb NL, Patten BM. Clinical correlations of anti-GM1 antibodies in amyotrophic lateral sclerosis and neuropathies. Muscle Nerve 1991;14 1021-7.

40 Nobile-Orazio E, Carpo M, Legname G, Meucci N, Sonnino S, Scarlato G. Anti-GM1 antibodies in motor neuron disease and neuropathy. Neurology 1990;40:1747-50.

41 Braun PE, Frail DE, Latov N. Myelin-associated glycoprotein is the antigen for a monoclonal IgM in polyneuropathy. F Neurochem 1982;39: 1261-5.

42 Steck AJ, Murray N, Meier C, Page N, Peruisseau G. Demyelinating neuropathy and monoclonal IgM antibody to myelin-associated glycoprotein. Neurology 1983;33:19-23.

43 Smith IS, Kahn SN, Lacey BW, et al. Chronic demyelinating neuropathy associated with benion IgM paraproteinaemia. Brain 1983;106:169-95.

44 Yeung KB, Thomas PK, King RMH, et al. The clinical spectrum of peripheral neuropathies associated with benign monoclonal IgM, IgG and IgA paraproteins. F Neurol 1991;238:383-91.

45 Stefansson KM, Marton LS, Antel JP, et al. Neuropathy accompanying IgM monoclonal gammopathy. Acta Neuropathol (Berl) 1983;59. 255-61.

46 Steck AJ, Murray N. Monoclonal antibodies to myelin-associated glycoprotein reveal antigenic structures and suggest pathogenic mechanisms. Springer Semin Immunopathol 1985;8:29-43.

47 Ilyas AA, Quarles RH, Dalakas MC, Fishman PH, Brady RO. Monoclonal IgM in a patient with paraproteinaemic polyneuropathy binds to gangliosides containing disialosyl groups. Ann Neurol 1985;18: 655-9.

48 Arai M, Yoshino H, Kusano Y, Yasaki Y, Ohnishi Y, Miyatake T. Ataxic polyneurop

49 Duane GC, Farrer RG, Dalakas MC, Quarles RH. Sensory neuropathy with monoclonal immunoglobulin $\mathrm{M}$ to GD1b ganglioside. Ann Neurol $1992 \cdot 31: 683-5$.

50 Obi T, Kusunoki S, Takatsu M, Mizoguchi K, Nishimura Y. IgM Mprotein in a patient with sensory-dominant neuropathy binds preferenprotein in a patient with sensory-dominant neuropathy binds pref

51 Yuki N, Miyatani N, Sato S, et al. Acute relapsing sensory neuropathy assciated with IgM antibody against B-series gangliosides containing a associated with IgM antibody against B-series gangliosides containing a $1992 ; 42: 686-9$.

52 Willison HJ, Paterson G, Veitch J, Inglis G, Barnett SC. Peripheral neu- 
ropathy associated with anti-Pr2 cold agglutinins: biochemical and immunocytochemical studies. I Neurol Neurosurg Psychiatry 1993;56: $1178-84$.

53 Herron B, Willison HJ, Veitch J, Roelcke D, Illis LS, Boulton FE. Monoclonal IgM cold agglutinins with anti-Pr $\mathbf{P}_{1 \mathrm{~d}}$ specificity in a patient with peripheral neuropathy. Vox Sang 1994;67:58-63.

54 Chiba A, Kusonoki S, Shimizu T, Kanazawa I. Serum IgG antibody to ganglioside GQ1b is a possible marker of Miller-Fisher syndrome. Ann Neurol 1992;31:677-9.

55 Willison HJ, Veitch J, Paterson G, Kennedy PGE. Miller-Fisher syndrome is associated with serum antibodies to GQ1b ganglioside. f Neurol Neurosurg Psychiatry 1993;56:204-6.

56 Yuki N, Sato S, Tsuji S, Ohsawa T, Miyatake T. Frequent presence of anti-GQ1b antibody in Fisher's syndrome. Neurology 1993;43:414-7.

57 Lewis RA, Sumner AJ, Brown MJ, Asbury AK. Multifocal demyelinating neuropathy with persistent conduction block. Neurology 1982;32: 958-64.

58 Pestronk A, Cornblath DR, Ilyas AA, et al. A treatable multifocal neuropathy with antibodies to GM1 ganglioside. Ann Neurol 1988;24:73-8.

59 Pestronk A, Adams RN, Clawson L, et al. Serum antibodies to GM1 ganglioside in amyotrophic lateral sclerosis. Neurology 1988;38: $1457-61$.

60 Pestronk A, Adams RN, Cornblath, et al. Patterns of serum antibodies to GM1 and GD1a gangliosides in ALS. Ann Neurol 1989;25:98-102.

61 Shy ME, Evans VA, Dublin FD, et al. Antibodies to GM1 and GDlb in patients with motor neuron disease without plasma cell dyscrasia. Ann Neurol 1989;25:511-3.

62 Salazas-Grueso EF, Routbort MJ, Martin J, et al. Polyclonal IgM antiGM1 ganglioside antibody in patients with motor neuron disease and variants. Ann Neurol 1990;27:558-63.

63 Willison HJ, Chancellor AM, Paterson G, Veitch J, Singh S, Whitelaw J, Kennedy PGE, Warlow CP. Antiglycolipid antibodies, immunoglobulins and paraproteins in motor neuron disease: a population based case control study. F Neurol Sci 1993;114:209-15.

64 Parry GJ, Clarke S. Multifocal acquired neuropathy masquerading as motor neuron disease. Muscle Nerve 1988;11:107-16.

65 van den Bergh P, Logigian EL, Kelly J Jr. Motor neuropathy with multifocal conduction blocks. Muscle Nerve 1989;11:26-31.

66 Krarup C, Stewart JD, Sumner AJ, et al. A syndrome of asymetrical limb weakness and motor conduction block. Neurology 1990;40:1 18-27.

67 Pestronk A, Chaudry V, Feldman EL, et al. Lower motor neuron syndromes defined by patterns of weakness, nerve conduction abnormalities, and high titres of anti-glycolipid antibodies. Ann Neurol 1990;27:316-26.

68 Chaudry V, Corse AM, Cornblath DR, et al. Multifocal motor neuropathy: response to human immune globulin. Ann Neurol 1993;33:237-42.

69 Feldman EL, Bromberg MB, Albers JW, Pestonk A. Immunosuppressive treatment in multifocal motor neuropathy. Ann Neurol 1991;30 $397-401$.

70 Chiba A, Kusonoki S, Obata H, Machinami R, Kanazawa I. Serum antiGQ1b IgG antibody is associated with opthalmoplegia in Miller-Fisher syndrome and Guillain-Barré syndrome. Neurology 1993;43:1911-7.

71 Yuki N, Sato S, Hozumi I, Miyatake T. An immunological abnormality common to Bickerstaff's brain stem encephalitis and Fisher's syndrome. common to Bickerstaff's brain
$\exists$ Neurol Sci 1993;118:83-7.

72 Nobile-Orazio E, Carpo M, Meucci N, et al. Guillain-Barre syndrome associated with high titers of anti-GM1 antibodies. F Neurol Sci 1992; associated

73 Vreisendorp FJ, Mishu B, Blaser MJ, Koski CL. Serum antibodies to GM1, GD1b, peripheral nerve myelin and Campylobacter jejuni in patients with Guillain-Barré syndrome and controls: correlation and prognosis. Ann Neurol 1993;34:130-5.

74 Enders U, Karch H, Toyka KV, et al. The spectrum of immune responses to Campylobacter jejuni and glycoconjugates in Guillain-Barre syndrome and other neuroimmunological disorders. Ann Neurol 1993;34:136-44.

75 Willison HJ, Paterson G, Kennedy PGE, Veitch J. Cloning of human antiGM1 antibodies from motor neuropathy patients. Ann Neurol 1994 35:471-8.

76 Hays AP, Latov N, Takatsu M, Sherman WH. Experimental demyelination of nerve induced by serum of patients with neuropathy and an antiMAG IgM M-Protein. Neurology 1987;37:242-56.
77 Willison HJ, Trapp BD, Bacher J, Dalakas M, Griffin JW, Quarles RH. Demyelination induced by intraneural injection of human anti-myelinDemyelination induced by intraneural injection of human anti-mye

78 Tatum AH. Experimental paraproteinaemic neuropathy, demyelination by passive transfer of human IgM anti-myelin-associated glycoprotein antibody. Ann Neurol 1993;33:502-6.

79 Gregory R, Thomas PK, King RHM, Hallam PLJ, Malcolm S, Hughes RAC, Harding AE. Coexistence of hereditary motor and sensory neuropathy type 1a and IgM paraproteinaemic neuropathy. Ann Neurol 1993;33:649-52.

80 Schwartz M, Seal BA, Eshhar N. Antibodies to gangliosides and myelin autoantigens are produced in mice after sciatic nerve injury. f Neurochem 1981;38:1192-5.

81 Schwerer B, Lassmann H, Kitz K, Bernheimer H. Ganglioside GM1, a molecular target for immunological and toxic attacks: similarity of neuropathological lesions induced by ganglioside antiserum and cholera toxin. Acta Neuropathol (Berl) 1986;72:55-61.

82 Thomas FP, Trojaborg W, Nagy C, et al. Experimental autoimmune neuropathy with anti-GM1 antibodies and immunoglobulin deposits at neuropathy with anti-GM1 antibodies and immunog
nodes of Ranvier. Acta Neuropathol 1991;82:378-83.

83 Santoro $M$, Uncini A, Corbo $M$, et al. Experimental conduction block induced by serum from a patient with anti-GM1 antibodies. Ann Neurol 1992;31:385-90.

84 Arakasi K, Kusonoki S, Kudo N, Kanazawa I. Acute conduction block in vitro following exposure to anti-ganglioside sera. Muscle Nerve 1993; 16:587-93.

85 Parry GJG. Anti-ganglioside antibodies do not necessarily play a role in multifocal motor neuropathy. Muscle Nerve 1994;17:97-9.

86 Lange DJ, Trojaborg W. Do anti-GM1 antibodies induce demyelination? Muscle Nerve 1994;17:105-7.

87 Heiman-Patterson T, Krupa T, Thompson P, Nobile-Orazio E, Tahmoush AJ, Shy ME. Anti-GM1/GD1b M-proteins damage human
spinal cord neurons co-cultured with muscle. $\mathcal{F}$ Neurol Sci 1993;120: 38-45.

88 Ohsawa T, Miyatake T, Yuki N. Anti-B series ganglioside-recognising autoantibodies in an acute sensory neuropathy patient cause cell death autoantibodies in an acute sensory neuropathy patient cause cell de
of rat dorsal root ganglion neurons. Neurosci Lett 1993;157:167-70.

89 Roberts M, Willison HJ, Vincent A, Newsom-Davis J. Serum factor in the Miller Fisher variant of Guillain-Barre syndrome blocks neurothe Miller Fisher variant of Guillain-Barre

90 Ilyas AA, Willison HJ, Quarles RH, et al. Serum antibodies to gangliosides in Guillain-Barré syndrome. Ann Neurol 1988;23:440-7.

91 Ilyas AA, Mithen FA, Chen Z-W, Cook SD. Search for antibodies to neutral glycolipids in sera of patients with Guillain-Barre syndrome. $\mathcal{F}$ Neurol Sci 1991;102:67-75

92 Ilyas AA, Mithen FA, Chen Z-W, Cook SD. Anti-GM1 IgA antibodies in Guillain-Barre syndrome. $f$ Neuroimmunol 1992;36:69-76.

93 Ilyas AA, Mithen FA, Dalakas MC, Chen Z-W, Cook SD. Antibodies to acidic glycolipids in Guillain-Barré syndrome and chronic inflammatory demyelinating polyneuropathy. $\mathcal{F}$ Neurol $S c i$ 1992;107:111-21.

94 Gregson NA, Jones D, Thomas PK, Willison HJ. Acute motor neuropathy with antibodies to GM1 ganglioside. Neurology 1991;238: 447-51.

95 Svennerholm L, Fredman P. Antibody detection in Guillain-Barre syndrome. Ann Neurol 1990;27:S36-S40.

96 van den Berg LH, Marrink J, de Jager AEJ, et al. Anti-GM1 antibodies in patients with Guillain-Barre syndrome. F Neurol Neurosurg Psychiatry 1992;55:8-11.

97 Walsh FS, Cronin M, Koblar S, et al. Association between glycoconjugate antibodies and Campylobacter infection in patients with GuillainBarre syndrome. $\mathcal{F}$ Neuroimmunol 1991;34:43-51

98 Nobile-Orazio E, Carpo M, Meucci N, et al. Guillain-Barre syndrome associated with high titers of anti-GM1 antibodies. F Neurol Sci 1992; 109:200-6.

99 Yuki N, Yoshino H, Sato S, Shinozawa K, Miyatake T. Severe acute axonal form of Guillain-Barre syndrome associated with IgG antiGD1a antibodies. Muscle Nerve 1992;15:899-903.

100 Simone IL, Annunziata P, Maimone D, Liguori M, Leante R, Livrea P. Serum and CSF anti-GM1 antibodies in patients with Guillain Barré syndrome and chronic inflammatory demyelinating polyneuropathy. f Neurol Sci 1993;114:49-55. 